\title{
The Effect of Two Semester Wrestling Training on University Students' Body Composition and Some Motoric Characteristics
}

\author{
Bilal Demirhan ${ }^{1,2}$ \\ ${ }^{1}$ Kyrgyz Turkish Manas University, School of Physical Education and Sport, Bishkek, Kyrgyzstan \\ ${ }^{2}$ Bartın University, Faculty of Sport Sciences, Bartın, Turkey \\ Correspondence: Bilal Demirhan, Faculty of Sports Science Coaching Education Department, Bartın, Turkey. \\ E-mail: bdemirhan@bartin.edu.tr
}

Received: January 26, 2020

Accepted: March 5, 2020

Online Published: May 24, 2020

doi:10.5539/ies.v13n6p26

URL: https://doi.org/10.5539/ies.v13n6p26

\begin{abstract}
The aim of this study was to examine the changes in the body composition and motor characteristics of the students attending the wrestling lesson in one academic year ( 8 months). The study included 19 male wrestler students with an average age of $21.20 \pm 1.61$ years. Body weights, body circumference measurements, regional muscle strengths, anaerobic strength skinfold thicknesses and body fat percentages were measured twice before the start of the wrestling training at the beginning of the academic year. SPSS 20.0 package program was used to analyze the data obtained at the beginning and end of the season. In the evaluation of pretest and posttest measurements, wrestler students' body weights, BMI, shoulder circumference, chest circumference, bicep circumference (ext), bicep circumference (flx), hip circumference, upper leg circumference, vertical jump distance, long jump distances, Anaerobic power capacities There was a statistically significant difference between the back force, leg strength, biceps, triceps and abdominal skin folds $(\mathrm{p}<0.05)$. As a result, it was determined that wrestling training taken by university students in a training process had a positive effect on muscle strength and anaerobic power levels and a positive effect on the development of body circumference measurements.
\end{abstract}

Keywords: university students, wrestling training, body composition

\section{Introduction}

In recent years, an increase has been observed in the studies investigating the body composition of Athletes. Determining the physical and physiological characteristics of the athletes whose body compositions and performance will be affected and observing their changes throughout the season is an important factor in the development of sporting success by shaping effective training programs.

Physical structure, which is one of the factors affecting performance, is physical properties in other words. Because physical structure or physical properties affect the presentation of physiological capacities. The physical structure is an important indicator of an athlete's high-level performance. Moreover, appropriate physical characteristics affect an athlete's performance positively (Maud \& Foste, 1995). Therefore, athletes often experience working to achieve elite athletes 'ideal' body type (Sundgot-Borgen \& Torstveit, 2011). It can affect the performance of the body's tissue composition deeply, especially in weight class sports. In addition, changes in muscle size become an important evaluation parameter during preparation for high-level competitions (Ackland et al., 2012).

It is stated that the high rate of sport branches-specific fat in athletes, muscle fibrils limit the contraction strength and contraction speed (Morehouse \& August, 1973). They also observed that athletes' body composition is of great importance in terms of disability and that athletes with high body fat ratio have a higher risk of sports injury and the recurrence rate of existing injury (Akhmedov et al., 2006). The biggest problem for athletes is the body fat they can carry without affecting their performance. In endurance sports, bodyweight above normal is a disadvantage for the athlete since it will reduce oxygen consumption per kilogram (Martin \& Drinkwater, 1991).

The physical structure is only one of the factors affecting performance and success. The physical structure, combined with other performance indicators such as strength, strength, flexibility, speed, endurance and quickness, which have the necessary motoric properties for the sports branch, positively affect the success of the athlete. In all sports, the impact of force on success is accepted by all. Especially in weight sports such as wrestling, 
the quality and quantity of force gain more importance.

In this study prepared in the light of this information, the changes in the body composition and some parameters that will affect the performance of wrestlers consisting of national athletes representing Kyrgyzstan in national and international competitions were examined during the 3-month preparatory season.

\section{Method}

The study included 19 male wrestlers who studied at the university and also regularly participated in wrestling training (Table 1). Measurements were recorded twice, at the beginning and at the end of the academic year (after 8 months). Voluntary consent form was taken from athlete students and the latest version of the Helsinki declaration was respected.

\subsection{Bodyweight, Height, Body Mass Index (BMI) Measurements}

Bodyweight of the participants was measured in a sensitive (Angel brand) scale up to 20 grams. Length measurements of the participants were measured with a Holtain sliding caliper with $1 \mathrm{~mm}$ measuring range. BMI values were calculated with the following formula using body weight and height (Pekcan, 2008).

BMI Formula:

$$
\text { BMI }(\mathrm{kg} / \mathrm{m} 2)=\text { Body weight }(\mathrm{kg}) / \text { Length }\left(\mathrm{m}^{2}\right) \text {. }
$$

\subsection{Skinfold Thickness and Body Fat Percentage Measurements}

Skinfold thicknesses were measured on the right side of the body with HOLTAIN brand skinfold caliper (Tamer, 1995). Body fat percentages were determined according to the LANGE formula.

Body Fat Percentage was determined by measuring skinfold thickness at 6 sites (chest, triceps, subscapular, suprailiac, abdomen, and thigh) and percentage fat calculated using the following formula (Gledhill \& Jamnik, 2003; Özer, 1993).

$$
\text { Percentage fat }=(\Sigma \text { skinfolds } \times 0.097)+3.64
$$

\subsection{Anaerobic Power Test}

The vertical jump performance of the participants was measured using a fixed platform with a precision of $0.1 \mathrm{~cm}$ prepared on the wall. The longest distances that participants could reach the platform first were recorded. He then made his knees bounce to the maximum with a 90-degree bend. The jump was repeated 3 times and the best score was recorded. An anaerobic power calculation was calculated using Lewis Formula (Özkan et al., 2010). Three trials were given. The maximum value among the 3 readings was used to calculate the anaerobic power by the Lewis formula.

Lewis Formula:

Anaerobic Power $=\sqrt{ } 4.9 \times$ body weight $(\mathrm{kg}) \times \sqrt{ }$ high jump distance $(\mathrm{m})$

\subsection{Body Circumference Measurements}

Body circumference measurements (Neck, Shoulder, Chest, Biceps-ex, Biceps-flx, Waist circumference, Hip circumference, Upper leg circumference, Lower leg) (table 3) were made with an anthropometric tape measure (Gulick Meter) with $\pm 1 \mathrm{~mm}$ precision.

\subsection{Statistical Evaluation}

Data has been analyzed by SPSS 20.00 package program. In the analysis, it was checked whether or not the data fulfilled the parametric test assumption. The paired sample t-test was used for the data providing the parametric test assumption. Significance level was taken as $\mathrm{p}<0.05$

\section{Results}

Table 1 shows the averages of changes in the body composition and strength characteristics of the wrestler student athletes, measured at different times and included in the study. 
Table 1. Paired sample t-test results before and after wrestling trainings (n:19)

\begin{tabular}{|c|c|c|c|c|}
\hline Variable & $\begin{array}{l}\text { 1.measurements } \\
\text { mean } \pm \text { sd }\end{array}$ & $\begin{array}{l}\text { 2. measurements (after } 8 \text { months) } \\
\text { mean } \pm \text { sd }\end{array}$ & $\mathrm{t}$ & $\mathrm{p}$ \\
\hline Age (Year) & $21.20 \pm 1.61$ & - & - & - \\
\hline Length (cm) & $174.30 \pm 5.99$ & - & - & - \\
\hline Body Weigh (kg) & $74.05 \pm 9.37$ & $75.00 \pm 9.05$ & 2.43 & $0.03^{*}$ \\
\hline BMI (body mass index) & $24.27 \pm 1.71$ & $24.59 \pm 1.58$ & 2.39 & $0.03^{*}$ \\
\hline Body fat (\%) & $9.25 \pm 1.33$ & $8.90 \pm 1.11$ & 1.65 & 0.12 \\
\hline Neck Circumference (cm) & $38.68 \pm 1.55$ & $39.13 \pm 1.67$ & 1.85 & 0.08 \\
\hline Shoulder Circumference $(\mathrm{cm})$ & $116.18 \pm 5.49$ & $117.23 \pm 5.41$ & 2.29 & $0.03^{*}$ \\
\hline Chest Circumference $(\mathrm{cm})$ & $96.26 \pm 5.81$ & $96.86 \pm 5.84$ & 5.11 & $0.00^{*}$ \\
\hline Biceps Circumference-ext (cm) & $29.28 \pm 2.12$ & $30.20 \pm 1.94$ & 5.90 & $0.00^{*}$ \\
\hline Biceps Circumference-flx (cm) & $31.47 \pm 1.92$ & $32.92 \pm 2.29$ & 4.89 & $0.00^{*}$ \\
\hline Waist Circumference (cm) & $78.86 \pm 5.81$ & $79.84 \pm 5.73$ & 1.92 & 0.07 \\
\hline Hip Circumference (cm) & $95.55 \pm 6.93$ & $96.47 \pm 6.34$ & 3.10 & $0.01^{*}$ \\
\hline Femur Circumference (cm) & $35.50 \pm 2.45$ & $36.60 \pm 2.28$ & 4.91 & $0.00 *$ \\
\hline Lower Leg Circumference (cm) & $21.78 \pm 1.48$ & $21.89 \pm 1.54$ & 0.45 & 0.65 \\
\hline Vertical jump (cm) & $0.62 \pm 0.16$ & $0.77 \pm 0.13$ & 5.59 & $0.00^{*}$ \\
\hline Anaerobic power $(\mathrm{kgm} / \mathrm{sn})$ & $127.69 \pm 17.49$ & $130.56 \pm 20.06$ & 2.22 & $0.04^{*}$ \\
\hline sup-kapula skinfold (mm) & $11.94 \pm 4.11$ & $11.21 \pm 4.33$ & 1.54 & 0.14 \\
\hline Triceps skinfold (mm) & $10.01 \pm 2.19$ & $9.18 \pm 2.05$ & 2.54 & $0.02^{*}$ \\
\hline Biceps skinfold (mm) & $5.45 \pm 1.75$ & $4.97 \pm 1.57$ & 2.63 & $0.02^{*}$ \\
\hline Chest skinfold (mm) & $8.56 \pm 3.31$ & $8.02 \pm 2.63$ & 1.56 & 0.14 \\
\hline Suprailiak skinfold (mm) & $9.15 \pm 4.55$ & $8.68 \pm 2.59$ & 0.45 & 0.65 \\
\hline Abdomen skinfold (mm) & $14.36 \pm 3.83$ & $12.23 \pm 3.04$ & 3.57 & $0.01^{*}$ \\
\hline Thigf skinfold (mm) & $12.78 \pm 4.12$ & $11.86 \pm 3.20$ & 1.15 & 0.27 \\
\hline
\end{tabular}
$\mathrm{p}<0.005$.

The results of the first measurement of wrestling students and the second measurements made after 8 months are given in (Table 1). According to these results, there was a statistically significant difference between body weights, BMI, shoulder circumference, chest circumference, biceps circumference (ext), biceps circumference (flx), hip circumference, upper leg circumference measurements of biceps, triceps and abdominal skin folds $(\mathrm{p}<0.05)$.

Table 2. Some motoric features paired sample t-test results before and after wrestling trainings (n: 19)

\begin{tabular}{|c|c|c|c|c|}
\hline Variable & $\begin{array}{l}\text { 1. measurements } \\
\text { mean } \pm \text { sd }\end{array}$ & $\begin{array}{l}\text { 2. measurements (after } 8 \text { months) } \\
\text { mean } \pm \text { sd }\end{array}$ & $\mathrm{t}$ & $\mathrm{p}$ \\
\hline Vertical jump $(\mathrm{cm})$ & $0.62 \pm 0.16$ & $0.77 \pm 0.13$ & 5.59 & $0.00^{*}$ \\
\hline Anaerobic power $(\mathrm{kgm} / \mathrm{sn})$ & $127.69 \pm 17.49$ & $130.56 \pm 20.06$ & 2.22 & $0.04^{*}$ \\
\hline Long jump (cm) & $227.78 \pm 9.52$ & $240.94 \pm 11.48$ & 9.36 & $0.00^{*}$ \\
\hline Flexibility (cm) & $36.44 \pm 3.84$ & $36 \pm 3.36$ & 0.81 & 0.43 \\
\hline Claw strength $(\mathrm{kg})$ & $51.14 \pm 6.10$ & $52.37 \pm 5.73$ & 1.22 & 0.24 \\
\hline Back strength $(\mathrm{kg})$ & $120.94 \pm 20.83$ & $124.10 \pm 19.52$ & 2.76 & $0.01^{*}$ \\
\hline Leg strength $(\mathrm{kg})$ & $139.47 \pm 32.95$ & $151.57 \pm 34.32$ & 5.84 & $0.00^{*}$ \\
\hline
\end{tabular}

$\mathrm{p}<0.005$.

The results of the first measurement of wrestling students and the second measurements made after 8 months are given in (Table 2). According to these results, there was a statistically significant difference between Vertical jump distance, long jump distances, Anaerobic power capacities, Back force, leg force measurements $(p<0.05)$.

\section{Discussion}

As it is known, the physical and physiological characteristics of the athletes that are monitored during the season are important factors in shaping effective training programs. The data obtained from the athletes during the preparatory season gives tangible data about the successful or unsuccessful season. 
In the study, the average body weight values measured in the university team and at the beginning of the preparatory period of the wrestlers participating in international competitions were recorded as $74.05 \pm 9.37 \mathrm{~kg}$. At the end of the season, the average body weight was measured as $75 \pm 9.05 \mathrm{~kg}$ and an increase of $1 \mathrm{~kg}$ was observed, although it was not statistically significant. The increase in body weight averages was thought to be effective in significantly increasing BMI and body circumference measurements (Shoulder, Chest, Biceps-ex, Biceps-flx, hip and upper leg). Our research findings are consistent with the previously reported results by (Cicioğlu et al., 2007; Aslan, 2013; Gökdemir et al., 1999).

Also, Anaerobic power averages measured $127.69 \pm 17.49 \mathrm{kgm} / \mathrm{s}$ at the beginning of the season increased significantly at the end of the season and increased to $130.56 \pm 20.06(\mathrm{p}<0.05)$. In addition to the vertical leap, which is important for the determination of anaerobic power, Durarak long jump scores were found to increase statistically significantly at the end of the season compared to the pre-season $(p<0.05)$. The average of the wrestlers' back forces at the beginning of the season $120.94 \pm 20.83 \mathrm{~kg}$ was determined as. At the end of the season, it was measured as $124.10 \pm 19.52 \mathrm{~kg}$ and it was observed that it increased significantly $(\mathrm{p}<0.05)$. Leg force, another force parameter, is $139.47 \pm 32.95 \mathrm{~kg}$ at the beginning of the season and with the positive effect of the training, at the end of the preparatory season, $151.57 \pm 34.32 \mathrm{~kg}$. It has been determined that the average is $(p<0.05)$. It was thought that the significant increase in the leg forces of the wrestlers brought about an increase in the anaerobic power. Indeed, the average measurement of the upper leg circumference was $35.50 \pm 2.45 \mathrm{~cm}$ at the beginning of the season, $36.60 \pm 2.28 \mathrm{~cm}$ at the end of the season. It was measured and found to be significantly excreted $(\mathrm{p}<0.05)$.

In a study on the subject, Welsman et al. (1997) reported a significant relationship between leg muscle volume and anaerobic performance. Another study stated that the width of the thigh circumference and consequently was effective in producing higher anaerobic power in excess of muscle fibers (Grant, 1996). This result is important to support our research findings. As it is known, one of the most important motoric features for wrestling athletes is muscle strength. In a study, it has been stated that body parts must have the necessary muscle strength in order to apply mobility skills and techniques (Aydos et al., 2009). In addition, they reported that forearm and leg strength were important factors in success in mid-level wrestlers (Cisar et al., 1987). The significant increases in the strength and anaerobic power parameters obtained in our study results can be interpreted as a concrete indication that the preparatory period training of the athletes was efficient. In similar studies, it was reported by many researchers that regular wrestling trainings caused an increase in regional muscle strength (Cicioğlu et al., 2007).

The average skinfold thickness measured from the wrestlers' Pazu, Triceps and abdominal regions was also significantly lower at the end of the training season compared to before $(p<0.05)$. In addition, body fat rates decreased at the end of the season compared to the beginning of the preparatory season. However, this decline was not statistically significant. In our study, body fat percentages were obtained by using skinfold thickness. Accordingly, there is a lot of research on long-term training that body fat rates tend to decrease (Burke et al., 1986; Demirel et al., 2015; Karakas et al., 2005; Stamford, 1983). The reduction in skinfold thickness was thought to be due to the increase in muscle mass occurring in environmental measurements. Thus, in our study (Shoulder, Chest, Biceps-ex, Biceps-flx, hip and upper leg) circumference measurements increased significantly at the end of the season $(\mathrm{p}<0.05)$. The increase in muscle mass brings with it a decrease in the fat rate. In a study conducted in this direction, Utter (2001) investigated the change of body composition in high school wrestlers as a result of a research that revealed a significant difference in wrestlers in body mass and lean muscle mass in high school wrestlers. He reported that the rate of lean muscle mass continued throughout the season, while body mass loss occurred.

\section{Conclusion}

As a result, it was concluded that the increase in body environmental measurements with the effect of training may be effective in the increase of anaerobic power and muscle strength properties with the increase of muscle volumes.

\section{References}

Ackland, T. R., Lohman, T. G., Sundgot-Borgen, J., Maughan, R. J., Meyer, N. L., Stewart A. D., \& Müller, W. (2012). Current status of body composition assessment in sport. Sports Medicine, 42(3), 227-249 https://doi.org/10.2165/11597140-000000000-00000

Akhmedov, R., Demirhan, B., Cic1oglu, I., Canuzakov, K., Turkmen, M., \& Gunay, M. (2016). Injury by regions seen in greco-roman \& freestyle wrestling. Turkish Journal of Sport and Exercise, 18(3), 99-107.

Aslan, C. A., Karakollukçu, M., Gül, M., \& Fişne, M. (2013). comparison of annual changes in selected physical and motoric characteristics in age 13-15 wrestlers. Turkish Journal of Sport Medicine, 48, 1-7. 
Aydos, L., Taş, M., Akyüz, M., \& Uzun, A. (2009). Investigatıon of The Relationship Between Strength and Some Anthropometric Parameters in Young Elite Wrestlers. Beden Eğitimi ve Spor Bilimleri Dergisi, 11(4), $1-10$.

Burke, L. M., Gollan, R. A., \& Read, R. S. (1986). Seasonal changes in body composition in Australian Rules footballers. British Journal of Sports Medicine, 20(2), 69-71. https://doi.org/10.1136/bjsm.20.2.69

Cicioğlu, İ., Kürkçü, R., \& Eroğlu, H. (2006). 15-17 Seasonal Changes on Some Antropometrical Characteristics of Wrestlers Aged 15-17 Years. Beden Ĕgitimi ve Spor Bilimleri Dergisi, 8(4), 3-9.

Cicioğlu, İ., Kürkçü, R., Eroğlu, H., \& Yüksek, S. (2007). 15-17 yaş grubu güreş̧ilerin fiziksel ve fizyolojik özelliklerinin sezonsal değişimi. Spormetre beden eğitimi ve spor bilimleri dergisi, 5(4), 151-156. https://doi.org/10.1501/Sporm_0000000085

Cisar, C. J. (1987). Pre-seasonal Body Composition, Built and Strength as Predictors of High School Wrestling Success. Applying Sports Sciences Research, 1, 66-70. https://doi.org/10.1519/00124278-198711000-00002

Demirel, N., Özbay, S., Kaya, F., \& Bayram, M. (2015). Elit güreşçilerde uygulanan aerobik ve anaerobik antrenman programının vücut kompozisyonu üzerine etkileri. International Journal of Social Sciences and Education Research, 3(2), 675-682. https://doi.org/10.24289/ijsser.288803

Gledhill, N., \& Jamnik, V. (2003). Detailed Fitness and Medical Assessment Protocols for NHL Entry Draft Players. Toronto, Ont: York University.

Gökdemir, K., Çeker B., \& Cicioğlu H. İ. (1999). Çabuk kuvvet antrenmanlarının 16-17 yaş grubu güreşçilerin bazı fiziksel ve fizyolojik parametreleri üzerine etkisi. Selçuk Üniversitesi Beden Eğitimi ve Spor Bilimleri Dergisi, 1, 36-43.

Grant, S., Hynes, V., Whittaker, A., \& Aitchison, T. (1996). Anthropometric, Strength, Endurance and Flexibility Characteristics of Elite and Recreational Climbers. Journal of Sports Sciences, 14, 301-309. https://doi.org/10.1080/02640419608727715

Karakas, S., Taser, F., \& Yıldız, Y. (2005). Tıp fakültesi ve spor yüksekokulu öğrencilerinde biyoelektriksel impedans analiz yöntemi ile vücut kompozısyonlarının karsılastııılması. ADÜ Tip Fakültesi Dergisi, 6(3), $5-9$.

Martin, A. D., Drinkwater, D. T. (1991). Variability in the measures of body fat. Sports Medicine, 11(5), 227-288. https://doi.org/10.2165/00007256-199111050-00001

Maud, P. J., \& Foster, C. (1995). Physiological Assessment of Human Fitness. USA, Human Kinetics.

Morehouse, E., \& August, M. (1973). Egzersiz Fizyolojisi (Çev. N.Akün). Ege Üniversitesi Yayını, Izmir.

Özer, M. (1993). Antropometri: Sporda Morfolojik Planlama. Kazanc1 Matbaacılık, İstanbul.

Özkan, A., Köklü, Y., \& Ersöz, G. (2010). Anaerobik performans ve ölçüm yöntemleri. Ankara: Gazi Kitapevi.

Pekcan, G. (2008). Beslenme Durumunun Saptanması. Diyet El Kitabı. 5. Baskı. Ankara, Hatiboğlu Yayınları.

Stamford, B. (1983). The Results of Aerobic Exercise. The Physician and sports medicine, 11(9), 145. https://doi.org/10.1080/00913847.1983.11708642

Sundgot-Borgen, J., \& Garthe, I. (2011). Elite athletes in aesthetic and Olympic weight-class sports and the challenge of body weight and body compositions. Journal of Sports Sciences, 29(1), 101-114. https://doi.org/10.1080/02640414.2011.565783

Tamer, K. (1995). Sporda Fiziksel, Fizyolojik Performansın Ölçülmesi ve Değerlendirilmesi. Ankara, Türkerler Kitapevi.

Utter, A. C. (2001). The new National Collegiate Athletic Association wrestling weight certification program and sport-seasonal changes in body composition of college wrestlers. J Strength Cond Res, 15(3), 296-301. https://doi.org/10.1519/1533-4287(2001)015<0296:tnncaa $>2.0 . c 0 ; 2$

Welsman, J. R., Armstrong, N., Kirby, B. J., Parsons, G., \& Sharpe, P. (1997). Exercise performance and magnetic resonance imaging-determined thigh muscle volume in children. Eur. J. Appl. Physiol., 76, 92-97. https://doi.org/10.1007/s004210050218 


\section{Copyrights}

Copyright for this article is retained by the author(s), with first publication rights granted to the journal.

This is an open-access article distributed under the terms and conditions of the Creative Commons Attribution license (http://creativecommons.org/licenses/by/4.0/). 